$$
\begin{aligned}
& \text { DEPARTMENT OF THE INTERIOR } \\
& \text { UNITED STATES GEOLOGICAL SURVEY }
\end{aligned}
$$

\title{
AEROMAGNETIC MAP OF THE EAST KILLINGLY QUADRANGLE AND PART OF THE ONECO QUADRANGLE CONNECTICUT AND RHODE ISLAND \\ By
}

P. W. Philbin and C. W. Smith

GEOPHYSICAL INVESTIGATIONS

MAP GP-591

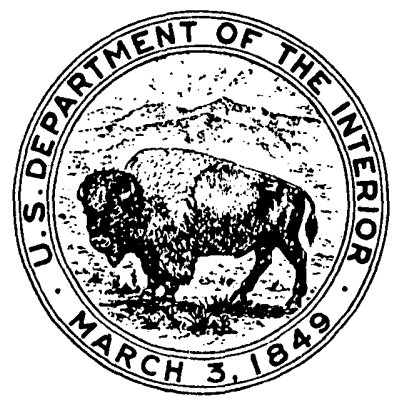

